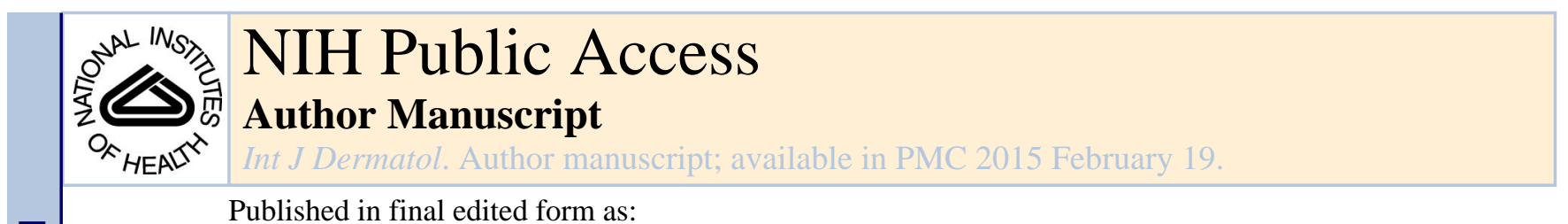

Published in final edited form as:

Int J Dermatol. 2013 August ; 52(8): 987-989. doi:10.1111/j.1365-4632.2011.05275.x.

\title{
Elephantiatic dermopathy
}

Paul Madaj, MD1, Laron McPhaul, MD², and Andrew G. Gianouka, MD1

${ }^{1}$ Division of Endocrinology, Harbor-UCLA Medical Center and the David Geffen School of Medicine at the University of California Los Angeles (UCLA), Los Angeles, CA, USA

${ }^{2}$ Department of Pathology, Harbor-UCLA Medical Center and the David Geffen School of Medicine at the University of California Los Angeles (UCLA), Los Angeles, CA, USA

\section{Case report}

A 47-year-old White woman (body mass index [BMI]: 24), with a history of childhood Graves' disease for which she had been treated with radioactive iodine at the age of 13 years, presented with severe hypothyroidism and elephantiatic lower extremities (Fig. 1). The patient did not exhibit ophthalmopathy. Neck examination did not reveal thyromegaly or lymphadenopathy. The findings in the lower extremities had begun eight years prior to presentation and had progressively worsened over time. The patient had been poorly compliant with thyroid hormone replacement therapy for many years as she found the preparations subjectively intolerable. At presentation, the patient's Thyroid-stimulating hormone (TSH) level was $168.16 \mathrm{IU} / \mathrm{ml}$ (normal range: $0.34-5.60 \mathrm{IU} / \mathrm{ml})$, free $\mathrm{T}_{4}\left(\mathrm{FT}_{4}\right)$ was $<0.40$ (normal range: $0.73-1.95 \mathrm{ng} / \mathrm{dL}$ ) and free $\mathrm{T}_{3}\left(\mathrm{FT}_{3}\right.$ ) was $1.9 \mathrm{pg} / \mathrm{mL}$ (normal range: 2.5-3.9 pg/ml). Thyroid-stimulating immunoglobulins (TSIs) were undetectable. A biopsy taken from the upper edge of the pathologic lesion on the left leg showed dermal edema, proliferation of capillary vessels, and mild fibrosis with a normal epidermis (Fig. 2). A second tissue sample taken from the mid portion of the left leg lesion showed dermal fibrosis, proliferation of capillary vessels, focal stromal hemosiderin deposition, and a hyperkeratotic epidermis. Increased numbers of mast cells were identified in both specimens. Colloidal iron (Fig. 3) and Alcian blue (not shown) stains were negative.

\section{Discussion}

The clinical presentation was suggestive of pretibial myxedema. However, of a series of 178 dermopathy patients described by Schwartz et al. ${ }^{1}$, only five did not exhibit some degree of ophthalmopathy. Additionally, another study found that all dermopathy patients in whom anti-thyrotropin receptor antibodies were measured, demonstrated high antibody titers. ${ }^{2}$ Furthermore, in our case, dermopathy tissue staining failed to disclose the presence of glycosaminoglycans, a hallmark of pretibial myxedema. Therefore, the diagnosis of pretibial myxedema should be called into question; what alternative diagnoses should be considered? Morbid obesity has been associated with pretibial lymphedematous mucinosis mimicking

(C) 2013 The International Society of Dermatology

Correspondence: Andrew G. Gianoukakis, MD, 1124 West Carson Street, Torrance, CA 90502, USA, agianouk@ucla.edu. Conflicts of interest: None. 
that seen in Graves' dermopathy; however, our patient's BMI was 24 and mucin was absent on histopathology. ${ }^{3}$

Several studies have noted the difficulties in differentiating elephantiatic pretibial myxedema from elephantiatic lymphedema. Causes of elephantiatic lymphedema include filarial causes (e.g. bacteria such as Wuchereria bancrofti, Brugia malayi and Brugia timori). Non-filarial causes of elephantiatic lymphedema include hereditary factors, sexually transmitted disease (lymphogranuloma venereum), leishmaniasis, leprosy, stasis dermatitis, generalized myxedema and others (Table 1). Our patient has no history of or risk factors for any of these conditions. Pretibial myxedema is characterized by a hyperkeratotic epidermis, mild acanthosis, papillomatosis, and significant mucin deposition in the middle and lower dermis. The upper dermis is characteristically unaffected. Widened intercellular spaces, abundance of collagen fibers, and the presence of mast cells are also described as classic features. ${ }^{4,5}$ Elephantiatic lymphedema is characterized by increased amounts of ground substance separating collagen bundles in the papillary dermis, fragmentation and degeneration of elastic fibers, dilated lymphatics, increased numbers of mast cells, hyperkerato-sis and acanthosis of the epidermis, with vascular proliferation and dermal fibrosis in more advanced lesions. ${ }^{6}$ The pathology in this case could be consistent with lymphedema with or without venous stasis. ${ }^{7}$ Separation of collagen bundles (Fig. 2) and an increased number of mast cells similar to that found in pretibial myxedema were apparent, but stains for stromal mucin were negative. The proliferation of capillary vessels in the upper dermis is unusual in Graves' disease-associated pretibial myxedema, ${ }^{8}$ but is characteristic of lymphedema and venous stasis.

In summary, the histologic changes seen in our patient are consistent with chronic lymphedema and fibrosis. In addition to the causes listed in Table 1, these conditions can be acquired and considered idiopathic. Minor bouts of cellulitis or other inflammatory conditions of the legs can induce lymphedema, which may present as severely as in the present patient. Longstanding hypothyroidism may have also contributed to our patient's condition. Although it is unlikely, we cannot exclude the possibility that our patient may have exhibited pretibial myxedema in the past. The autoimmune process may ultimately have subsided and the glycosaminoglycan deposition resolved, leaving the patient with the consequences of the previous insult and a self-perpetuating cycle of secondary lymphedema.

Although the definitive diagnosis remains unclear, our patient has shown compliance with thyroid hormone therapy and is undergoing complete decongestive physiotherapy as suggested by Susser et al., ${ }^{9}$ with modest initial success to date.

\section{References}

1. Schwartz KM, Fatourechi V, Ahmed DD, Pond GR. Dermopathy of Graves' disease (pretibial myxedema): longterm outcome. J Clin Endocrinol Metab. 2002; 87:438-446. [PubMed: 11836263]

2. Fatourechi V, Bartley GB, Eghbali-Fatourechi GZ, et al. Graves' dermopathy and acropachy are markers of severe Graves' ophthalmopathy. Thyroid. 2003; 13:1141-1144. [PubMed: 14751035]

3. Rongioletti F, Donati P, Amantea A, et al. Obesity-associated lymphedematous mucinosis. J Cutan Pathol. 2009; 36:1089-1094. [PubMed: 19222694] 
4. Konrad K, Brenner W, Pehamberger H. Ultrastructural and immunological findings in Graves' disease with pretibial myxedema. J Cutan Pathol. 1980; 7:99-108. [PubMed: 6989863]

5. Kobayasi T, Danielsen L, Asboe-Hansen G. Ultrastructure of localized myxedema. Acta Derm Venereol. 1976; 56:173-185. [PubMed: 59503]

6. Bull RH, Coburn PR, Mortimer PS. Pretibial myxedema: a manifestation of lymphedema? Lancet. 1993; 341:403-404. [PubMed: 8094170]

7. Daroczy J. Pathology of lymphedema. Clin Dermatol. 1995; 13:433-444. [PubMed: 8665454]

8. Somach SC, Helm TN, Lawlor KB, et al. Pretibial mucin. Histologic patterns and clinical correlation. Arch Dermatol. 1993; 129:1152-1156. [PubMed: 8363399]

9. Susser WS, Heermans AG, Chapman MS, Baughman RD. Elephantiasic pretibial myxedema: a novel treatment for an uncommon disorder. J Am Acad Dermatol. 2002; 46:723-726. [PubMed: 12004314] 


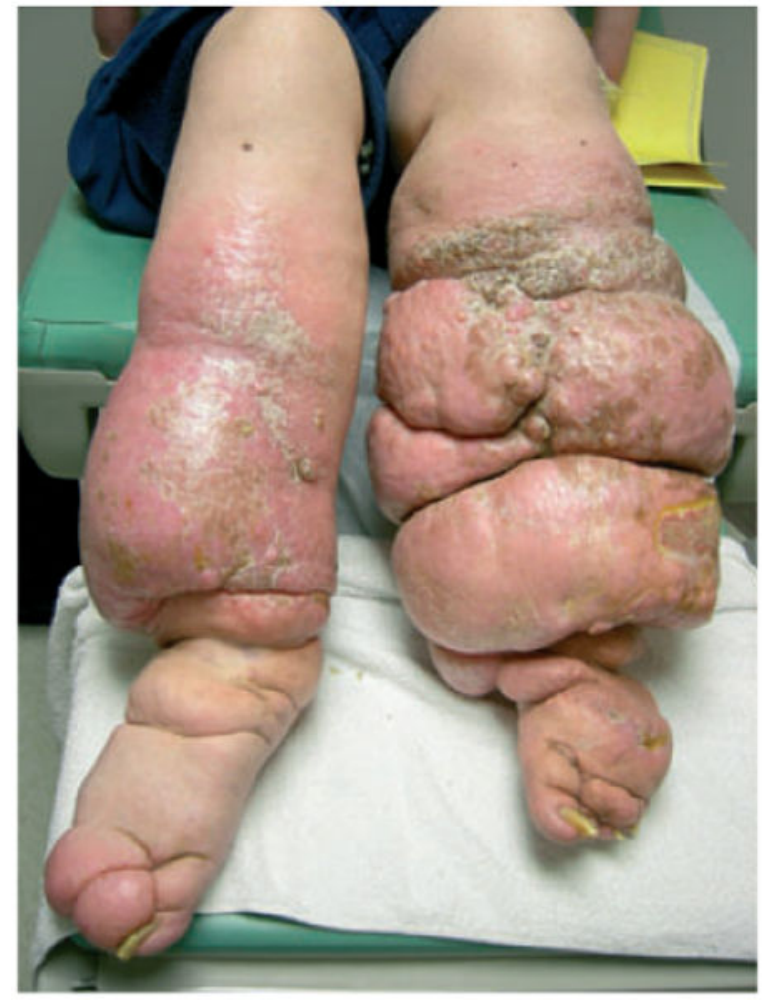

Figure 1. Elephantiatic dermopathy of the lower extremities 


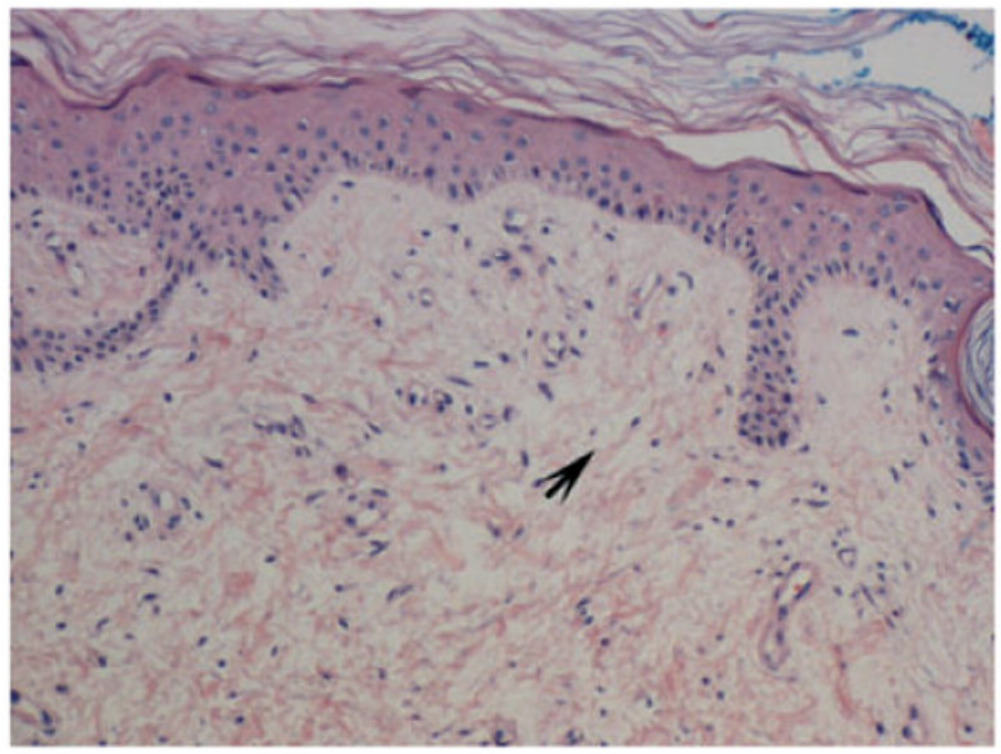

Figure 2. Histopathology shows the prominent separation of collagen bundles (arrow). Proliferation of capillary vessels is present. (Hematoxylin and eosin stain; original magnification $\times 200$ ) 


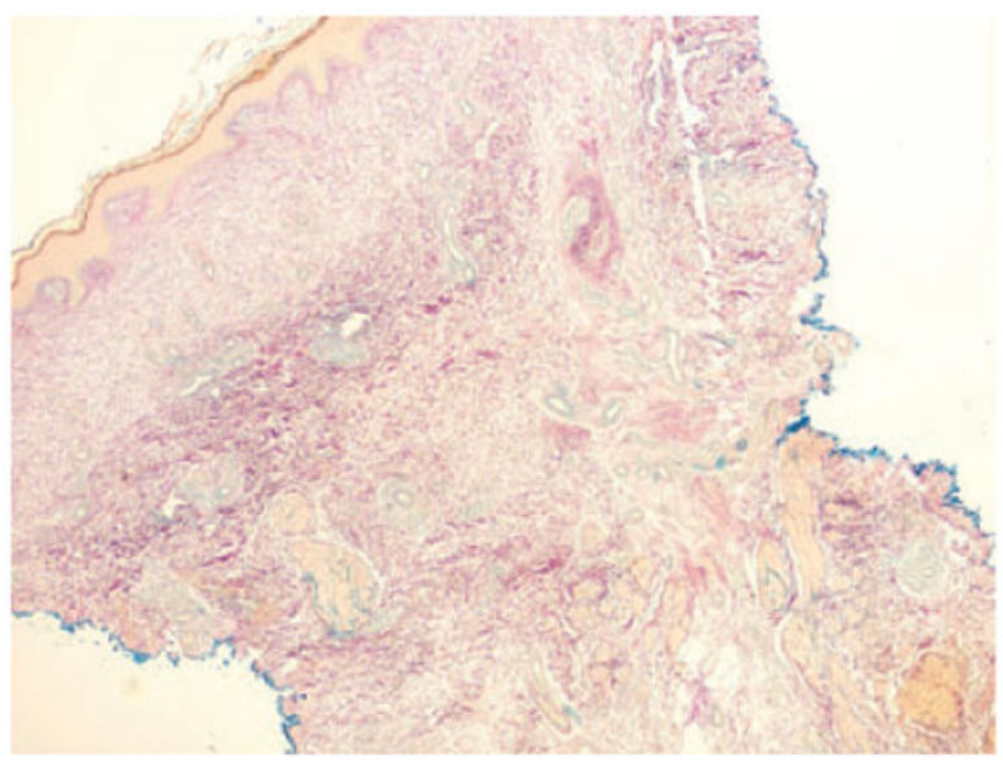

Figure 3. The blue-green staining of stromal mucin characteristic of pretibial myxedema is not apparent. (Colloidal iron stain; $\times$ 40) 


\section{Table 1}

\section{Causes of elephantiasis}

\begin{tabular}{|c|c|c|}
\hline \multicolumn{3}{|l|}{ Filariasis: bacterial causes } \\
\hline - Wuchereria bancrofti & - Brugia malayi & - Brugia timori \\
\hline \multicolumn{3}{|l|}{ Non-filarial causes } \\
\hline $\begin{array}{ll}\text { - } & \text { Podoconiosis } \\
\text { - } & \text { Leishmaniasis } \\
\text { - } & \text { Pretibial myxedema } \\
\text { - } & \text { Stasis dermatitis } \\
\text { - } & \text { Amyloidosis } \\
\text { - } & \text { Lichen myxedematosus } \\
\text { - } & \text { Lichen simplex chronicus } \\
\text { - } & \text { Scleromyxedema } \\
\text { - } & \text { Sexually transmitted disease (e.g. lymphogranuloma venereum) } \\
\text { - } & \text { Leprosy } \\
\text { - } & \text { Generalized myxedema } \\
\text { - } & \text { Urticarial phases of certain blistering eruptions (e.g. bullous, } \\
& \text { pemphigoid skin lesions) }\end{array}$ & $\begin{array}{ll}\text { - } & \text { Streptococcal lymphangitis } \\
\text { - } & \text { Tuberculosis } \\
\text { - } & \text { Hereditary factors } \\
\text { - } & \text { Lichen } \\
\text { - } & \text { Lichen planus } \\
\text { - } & \text { Follicular mucionosis } \\
\text { - } & \text { Insect bites } \\
\text { - } & \text { Reticular erythematous mucinosis } \\
\text { - } & \text { Fibrosing dermopathy } \\
\text { - } & \text { Trauma or repeated injury } \\
\text { - } & \text { Morbid obesity }\end{array}$ & \\
\hline
\end{tabular}

